\title{
Overcoming unsustainability: retrofitting American suburbs with high-density built environment
}

\author{
P. J. Armstrong \& M. M. Ali \\ School of Architecture, University of Illinois Urbana-Champaign, USA
}

\begin{abstract}
The problems of suburbs are well-known: suburban sprawl, dependency on automobiles and consequent waste of energy, greater carbon footprint, loss of land, etc. These problems can be overcome, before the suburbs reach a breaking point, with mixed-use high-rises and mid-rises in which living can be made enjoyable by creating the ground plane-like environment above with sustainable vertical urban design concepts. These new buildings can be built with recycled and re-usable materials, and clean-energy environmental technologies such as solar panels, wind energy, hydroelectric, and efficient cogeneration power plants. Air quality - both indoor and outdoor - can be improved and a community environment can be created by providing mixed-uses that bring together civic, education, recreation, exercise, and live/work functions and facilities. The compactness of the built environment and the high vertical density will allow walk-up communities with pedestrian-friendly walkways to stores, shopping, entertainment and other suburban commercial and mercantile neighborhoods. This will reduce the use of cars, make people healthier, and reduce traffic gridlock in the main city's central business district (CBD). A new 21 st century model is needed for the American suburbs that are stretching cities to their limits. While this paper focuses on American suburbs, the authors' proposition can be applied to the suburbs of cities internationally where similar conditions prevail.
\end{abstract}

Keywords: high-density, urban sprawl, compact communities, planning strategies, mixed-use development. 


\section{Introduction}

In recent years, a great deal of attention has been given to the design of cities and suburbs alike, but relatively little research has been conducted regarding the problem of increasing density, sustainability, and urban metabolism of suburbs with high-rise buildings. The purpose of the suburb at one time was to address the problems of overcrowding of cities due to industrialization, pollution of air and water, and the excessive migration from the country to the city of people who were searching for economic and social opportunities (Howard [1]; Barnett [2]). However, as suburbs grew and more people left the city a new problem arose: the migration of large urban populations onto land once reserved for agriculture and wild nature, and the decanting of the inner city of capital and prosperity to the suburbs leaving behind the poor, the uneducated, and the disenfranchised. Although there were many conspiring factors for this vast exodus, the automobile and the interstate highway, along with failing schools and the shuttering of factories, have been held accountable as primary contributors by many planners and critics for the decline of the city and the rise of the American suburb.

Today, there is almost universal agreement and concern that if this trend continues unabated cities in the traditional sense may cease to exist. Some urban designers have argued that we have already reached a point where cities themselves are being redefined and that the solutions for urban regeneration will be found in new planning concepts derived from ecology and sustainability as opposed to neo-traditional or modern precepts of urban planning and design (Waldheim [3]; Corner [4]). If this is the case, then cities will be radically transformed in form and scale not from Utopian or form-based planning methods, but more subtly from within through organic and evolutionary processes directed by social and political agents of reform.

Suburbs, like cities, evolve. As they grow and mature they undergo several transformations from bedroom communities comprised almost exclusively of single-family houses arranged along winding streets and cul-de-sacs into fullfledged satellite cities with schools, parks for recreation and industry, shopping centers, cultural amenities, and civic centers. Thus both the suburbs and the core cities are urbanized. It is this combination of city and suburb that is home to 80 percent of all Americans. This relationship will undoubtedly intensify in the near future with other metropolitan areas gradually overlapping to form megalopolises. Therefore, planning decisions must anticipate growth as a constant in all metropolitan areas.

Urban design is city-building. It brings together the many different parts and pieces of an environment to create a place. Therefore, urban designers must be generalists capable of bringing together diverse specialists and technicians to create a unified vision (UDA [5]). The Congress for New Urbanism views suburban sprawl, sustainable design, and preservation of agricultural lands and the historic heritage "as one interrelated community-building challenge" (CNU [6]). 
The purpose of this paper is to show how multi-use high-density can benefit the suburb and enhance its urban metabolism and sustainability. High-rise buildings are no longer relegated to the business districts of major cities. In recent years, they have been built in perimeter centers located along interstate highways, modern edge cities which border traditional or established cities, at transportation nodes, and in suburban office parks and new town centers. While some critics may justifiably argue that we should be moving more resources back into cities, our argument is that as long as those resources are located elsewhere, architects and planners must be prepared to address these relatively new suburban conurbations with the same care and attention as the traditional city has received in the past, but also with an eye to the future with ecology, density, and sustainability firmly in mind.

\section{Spatial planning for density}

The past 100 years have seen a population explosion unprecedented in human history. In 1900 , only around $14 \%$ of the world's population, or about 200 million people, lived in cities. At the beginning of the $21^{\text {st }}$ century, $50 \%$ of the people world-wide are city-dwellers. The World Bank predicts that by 2025, $80 \%$ of the people of developing countries will be living in cities (Gauzin-Muller [7]). Such uncontrolled growth often results in the destruction of arable land vital for food production, which necessitates the retrofitting of both cities and suburbs based on sustainable planning principles to consolidate transportation, infrastructure, and services within compact zones and promote land-use density through high-rise, mixed-use building strategies.

\subsection{Strategic planning}

A strategic framework at the urban regional level enables policy parameters to be explored and integrated to meet environmental and social objectives, such as increasing density and consolidating services, without compromising long-term urban development (Carter [8]). Strategies include 1) promoting institutional arrangements involving region-wide partnerships; 2) spatial scale creating region-wide strategic planning frameworks; 3) economic development linking local to city and regional development; 4) social cohesion to overcome social exclusion; 5) environmental access and amenities to overcome physical access of declining areas through transport planning; and, 6) improving housing to attract new residents (Hall [9]). These strategies can also be applied to retrofitting suburbs as a component of regional planning and economic development.

Fundamental strategies for retrofitting suburbs in a sustainable manner are adding mixed-use density to core areas, consolidating essential shared services, and developing public transport networks that link suburban residents to shopping and community services, as well as suburban communities to cities. "While the electric streetcar made middle-class suburbanization possible the automobile was to make suburbanization the dominant residential pattern" of the 20th century (Palen [10]). 
Figure 1 illustrates the increase in travel miles by automobile in the U.S. from 1900 to 2010 . The upward surge of the graph following the 1950 s indicates an increase in commuter travel from suburbs to cities.

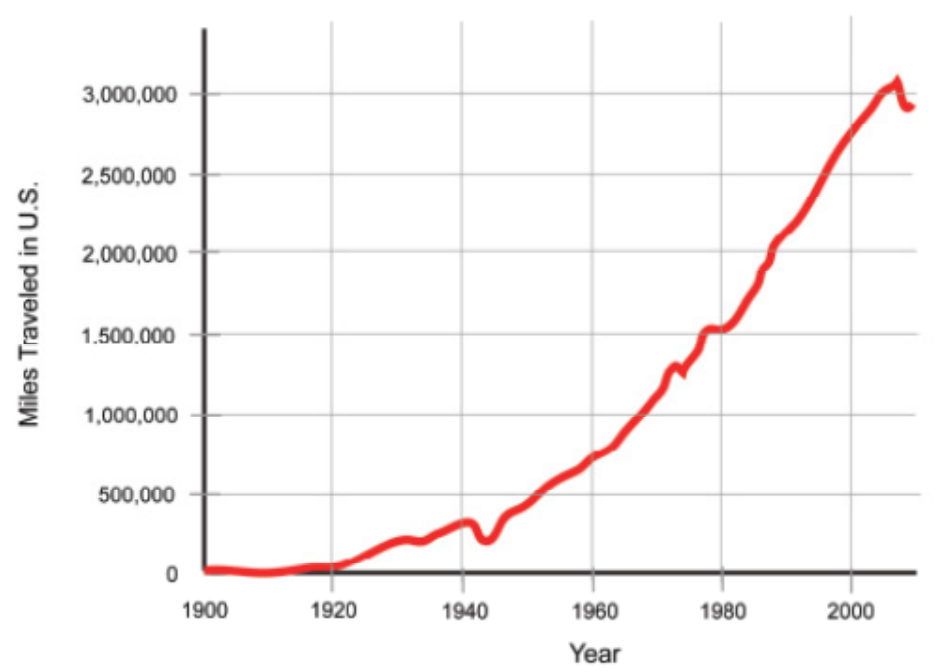

Figure 1: $\quad$ Miles traveled in the U.S. by automobile 1900-2010.

Alan E. Pisarski, a national authority on transportation and commuting, noted that "two-thirds of all job growth in the United States is going to the suburbs" (Pisarski [11]). Suburban Atlanta, for instance, has twice the office space as the center city. During the 1980s, Sears and Roebuck moved its corporate headquarters from its tower in downtown Chicago to a complex of low-rise office buildings at Prairie Stone located in Hoffman Estates, $5.6 \mathrm{~km}$ (35 mi) to the northwest.

One of the principal planning strategies for retrofitting suburbs, therefore, is designing density. Much of suburban settlement in the U.S. can be characterized as low density - one- or two-story buildings equally distributed on privately owned lots (Chow [12]). In older suburbs, hemmed in by neighboring communities, the limits of growth are palpable and there is no room to expand horizontally. The options are to revitalize use of existing housing stock and undeveloped pockets of land, and to build vertically integrating multi-uses. At the suburban edge, limits to growth are being debated and imposed, but the problem remains - how to grow sustainably without using all available land and natural resources. Consequently a "suburban limit line" has emerged, beyond which the regional infrastructure can no longer support development. Density is increased by packing and stacking volumes in ever tighter configurations, as shown in Figure 2. 


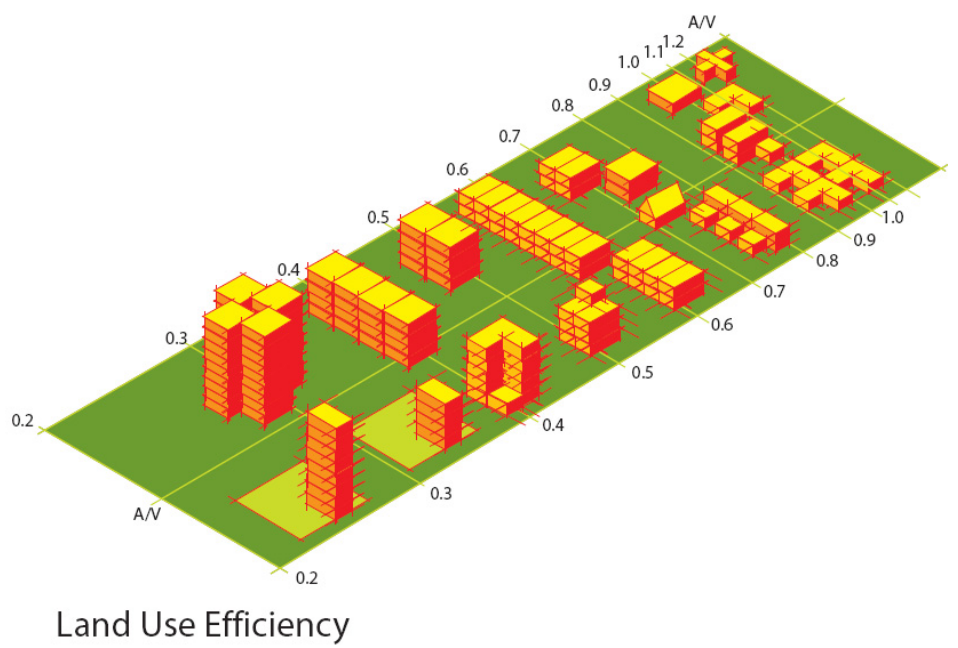

Figure 2: Land use efficiency. Note that tall buildings add density and use land more efficiently than horizontally distributed buildings.

"New Urbanist" planning approaches, including neo-traditional developments and transit-oriented developments, promote dense, pedestrianoriented planning strategies that create urban continuity and density through street planning, mixed-use development, and attached building types (Chow [12]). We can achieve even greater density by building vertically in landstarved expensive suburbs. But this approach also requires the integration of new uses such as retail, offices, and entertainment with residences, which often contradicts many existing zoning models that foster the segregation of uses. While they are not appropriate for entire suburbs, high-rise can be built in clusters in appropriate locations with the latest green design approaches employing state-of-the art technologies and sustainable planning strategies.

Mixed-use high-rises have the added benefit of bringing a new set of diverse functions and skilled people to suburban developments, which allow developers and municipalities to blend living, working, shopping, and entertainment into compact, pedestrian-oriented urban districts. Emphasizing vertical density as opposed to horizontal development creates smaller building footprints that decreases sprawl, conserves energy and material resources, centralizes transportation and vital services, and contributes to sustainable development and preservation of open land (Beedle et al. [13]).

\section{Retrofitting suburbs}

Migration patterns have transformed cities in unprecedented ways increasing pressures on existing transportation networks, service infrastructures, and institutional and governance systems. The most apparent effect has been the 
proliferation of highways linking suburban and peripheral communities to the CBD of the central city.

Each year development in the U.S. pushes out across more than 404,685 hectares (1,000,000 acres) turning huge expanses of farmland, forest, desert, and other rural landscapes into additional suburbs (Langdon [14]). People tend to feel more isolated in suburban areas that are often dominated by single-family homes with few cultural, recreational, and social amenities that are readily accessible. Consequently, work, shopping, education, recreation, and living are separated into discreet, autonomous geographic districts dictated by antiquated zoning ordinances and/or by developers, and financiers who are adverse to promoting diverse neighborhoods and activities. In short, suburban development with its emphasis on horizontal rather than vertical growth promotes sprawl, is detrimental to both the regional ecology and economy by spreading uses over a larger land area, increases the carbon footprint, decentralizes transportation, and takes valuable agricultural and forest land out of production; hence, it is fundamentally unsustainable.

In Table 1 we see comparisons of population growth for the cities proper and metropolitan statistical area (MSA) of Chicago, IL and Miami, FL, from 19002010. In each case, there is a discernable pattern of increasing growth in suburban and peripheral communities, with the central city either growing slightly (i.e.: Miami) or even shrinking in population (i.e., Chicago). While it is important to address the decline of the city, the focus of this paper is on the suburb, which has been taking on many functions of the central city without the density.

Table 1: City-region population change comparisons: Chicago, IL vs. Miami, FL.

\begin{tabular}{|c|c|c|}
\hline City or Metropolitan Area & 1950 Population & 2010 Population \\
\hline City of Chicago, IL & $3,620,962^{1}$ & $2,595,598^{2}$ \\
\hline Chicago, IL CMSA $^{a}$ & $6,869,699^{1}$ & \\
\hline Chicago CMSA MSA ${ }^{\text {b }}$ & & $8,239,820^{2}$ \\
\hline City of Miami, FL & $244,276^{1}$ & $399,307^{2}$ \\
\hline Miami, FL MSA ${ }^{c}$ & $693,705^{1}$ & $5,564,635^{2}$ \\
\hline \multicolumn{3}{|c|}{$\begin{array}{l}\text { aThe Chicago, IL MSA consists of Chicago-Naperville-Jolliet census areas (U.S. Census } \\
\text { Bureau, 2010). } \\
\text { Bo The Chicago, IL CMSA consists of Chicago-Gary-Kenosha-IL-IN-WI census areas (U.S, } \\
\text { Census Bureau 1950). } \\
\text { cThe Miami, FL MSA consists of Miami-Fort Lauderdale-Pompano Beach, FL Metropolitan } \\
\text { Area Statistical census areas (U.S. Census Bureau, 2010). } \\
\text { 1U.S. Census Bureau } 1950 .\end{array}$} \\
\hline
\end{tabular}


Introducing tall buildings into suburbs also must consider several prominent issues, such as transportation, demographics, and life-style patterns. Masstransportation - particularly in the US - must be developed to serve suburban high-rise developments. High-rise buildings do not always fit in scale with single-family homes and the life-style associated with concept of the "American Dream" of detached homes on large individual lots. The argument for density, which includes building tall, points to a demographic shift for the entire society. Thus, the existing suburban paradigm must be re-examined.

Transportation is a key element of urban and suburban redevelopment today. Langdon insists that "it is imperative to design suburbs in ways that make transportation difficulties less onerous and that foster a more enjoyable and convenient way of life" (Langdon [14]). To do so, he recommends that planners, developers, and city officials work together to develop a more coordinated approach to transportation, employment, shopping, and services that are concentrated in places that are compact and walkable. This also requires more emphasis on creating vertical density to reduce sprawl, bringing a mix of diverse activity zones and services in proximity to one another, and promoting more sustainable and creative planning approaches to anticipate future growth and promote greater urban density of suburban communities.

\section{Case studies}

Tall building developments in the suburbs are underway in many American cities. For example, we find this phenomenon growing is suburban Chicago including Evanston, Shaumberg, Arlington Heights, and Oak Brook; and suburban Miami - Coral Gables, Sunny Isles Beach, Aventura, and Coral Springs.

\subsection{Evanston, Illinois}

In many major cities, suburban development began as an extension of the city onto adjacent undeveloped land parcels. In Chicago, for instance, the city grew westward to Oak Park and northward to Evanston. Consequently, the existing grid pattern of urban streets and blocks of Chicago remained intact, albeit at a smaller scale, with more emphasis on creating pedestrian-friendly residential neighborhoods.

Evanston was made possible in 1853 when Northwestern University purchased and surveyed more than 121.4 hectares (300 acres) of swampy land, which is now central Evanston (Ebner [15]). It has always been a transit-oriented development (TOD) with easy access to Chicago's Loop business district. This has allowed Evanston to compete with auto-oriented suburban shopping centers, residential subdivisions, and green-field office parks. It is currently home to more than 75,000 residents and 4,000 jobs within $12.6 \mathrm{~km}^{2}(7.8 \mathrm{sq} \mathrm{mi})$ (Makarewicz et al. [16]). Today over 300 businesses, several high-rise office and residential buildings, three traditional low-rise shopping areas, an 18-screen movie theatre, and over 85 restaurants define the downtown (Ebner [15]). 
Because Evanston is surrounded by established communities, it has had to build up not out. Recent mid- and high-rise projects include the Optima Lofts and Optima Views condominiums, designed and developed by Chicago architect David Hovey, FAIA, and the Skyline at Evanston apartments, designed by Solomon Cordwell Buenz (Fig. 3). Hovey's award-winning projects go up with a speed that provides a competitive advantage. For example, the sleek, 28-story "Views" condominium high-rise in Evanston moved from foundations to first closing in 12 months. It includes 204 units, 240 parking spaces and $492.4 \mathrm{~m}^{2}$ $(5,300 \mathrm{sq} \mathrm{ft})$ of retail space (Bordenaro [17]).
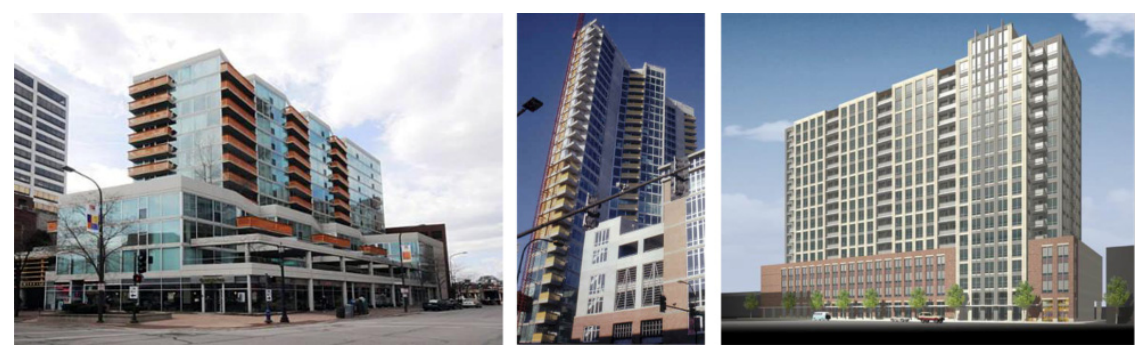

Figure 3: Optima Lofts (left) and Optima View (center), and the Skyline at Evanston (right) bring upscale urban living to downtown Evanston, IL.

The Skyline at Evanston apartments located at 415 Howard Street offers "Chicago lifestyle, Evanston address" located less than a block from Howard Station and the el (Apartment Home Living [18]). It features luxury apartment units with a 24-hour state-of-the-art fitness center and business center, 24-hour concierge service, private enclosed parking garage, and close proximity to Loyola and Northwestern University.

A 50-story high-rise rotating apartment building was approved by the Evanston City Council in March of 2011 to be erected near downtown on a site to be determined. The slender tower will have a minimal footprint and an underground garage several floors deep using a new foundation system designed for marshy conditions developed in China. The shape of the tower will fit practically any lot because it is fluid and it revolves. The fluidity permits each floor plan to react independently to environmental conditions depending on the sun's angles and intensity. Other innovations include retrievable balconies and levitating "wheel chairs" for handicapped accessibility (Macsai [19]).

\subsection{Coral Gables, Florida}

Miami has a mix of existing neighborhoods and established suburbs that reflect both its historical styles as well as modern high-rise developments. Retrofitting existing suburbs must add density, address sustainability through green technology, include mass transit options, and develop mixed-use high-rise buildings where appropriate. Coral Gables is a city in Miami-Dade County, Florida, southwest of Downtown Miami and has been home to the University of 
Miami since its founding in 1925. It is served directly by the Miami Metrorail at Douglas Road, University, and South Miami stations.

With a population of 42,871 , Coral Gables was one of the first planned communities in the US, and prefigured the development of the gated community and the homeowners association (U.S. Census Bureau). The city was developed by George Edgar Merrick during the Florida land boom of the 1920s. The city's architecture is almost entirely Mediterranean Revival Style. By 1926, the city covered 4,047 hectares (10,000 acres) had netted $\$ 150$ million in sales with over \$100 million spent on development (Overholser [20].

Coral Gables already has a compact downtown commercial district only four blocks wide and more than $3 \mathrm{~km}(2 \mathrm{mi})$ long, which promotes walking. With its affluent population, proximity to Miami International Airport, and a business district that is home to more than 175 multinational companies, Coral Gables has long been viewed as a haven of economic stability in South Florida's varied and volatile marketplace. There are at least seven new projects either under construction or scheduled to break ground soon in Coral Gables. The downtown section of Coral Gables, around Ponce De Leon Boulevard, is the epicenter of the mini-building boom, with luxury apartments and office buildings - not condos - taking center stage. The new projects could create up to 1,000 additional residential units and house dozens of additional companies and restaurants (Olorunnipa [21]).
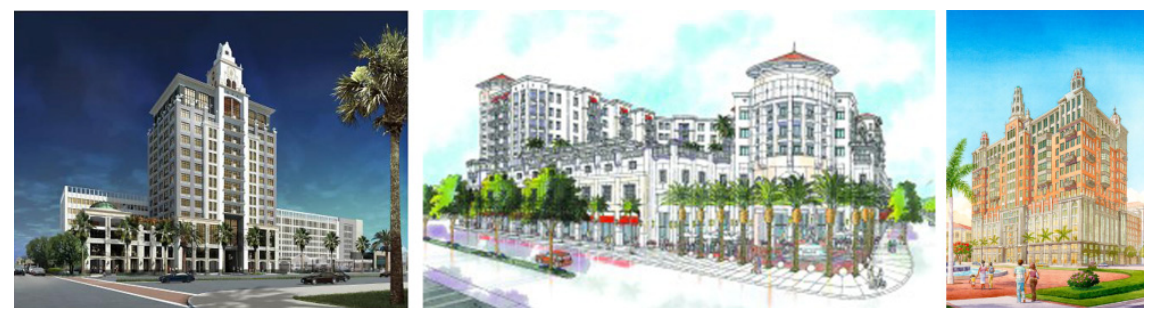

Figure 4: $\quad$ Proposed high-rises in Coral Gables, FL include 396 Alhambra (left), Gables Ponce Luxury Apartments (center), the Ponce de Leon Towers (right).

Three projects (Fig. 4) that feature high-rise density include 396 Alhambra, a 15-story tower, with office and retail space, Gables Ponce Luxury Apartments, and the mixed-use Ponce de Leon Towers, developed by the Allen Morris Co. 396 Alhambra, developed by Agave Holdings, LLC, is scheduled to open in 2012 and will feature $21,368 \mathrm{~m}^{2}(230,000 \mathrm{sq} \mathrm{ft})$ of space at a cost $\$ 140$ million to construct. The Gables Ponce Luxury Apartment Community is developed by Gables Residential and will have $34,503 \mathrm{~m}^{2}$ (371,392 sq ft) of mixed-use space when it is completed in December 2012 at a cost of $\$ 50$ million. The 16-story Ponce de Leon Towers will offer 19,138 $\mathrm{m}^{2}$ (206,000 sq ft) of living and retail space at a projected cost of $\$ 90$ million when it is completed in 2014 (Olorunnipa [21]). In each case, the developers are working with the city to 
increase high-rise density buildings in the downtown that are contextually compatible with Coral Gables' existing historic architecture.

\section{Conclusion}

According to the UN, world population is expected to grow from 6.1 billion in 2000 to 8.9 billion in 2050 increasing therefore by $47 \%$ (UNDESA [22]). It is estimated that more than $70 \%$ of the world's population will be living in megacities or metropolitan areas by 2050 (CBS News [23]). With these statistics on the exponential growth of world population in mind, it is imperative to retrofit suburbs with infill high-density development. This paper has shown that the livability, vitality, and metabolism of suburbs and metropolitan regions can be improved and sustained through a combination of strategic planning and densification of suburban centers. High- and mid-rise buildings need to be considered in the mix of options available to developers, and municipal governments when considering the future growth of the suburb. Mixed-use high-rises blend living, working, shopping, and entertainment into compact, pedestrian-oriented urban districts. Emphasizing vertical density as opposed to horizontal development creates smaller building footprints that decreases sprawl, conserves energy and material resources, reduces the carbon footprint, centralizes transportation and vital services, and contributes to sustainable development and preservation of open land.

The time has come when architects and urban planners must actively collaborate with other professionals and cities to retrofit existing suburbs to promote livable communities with pedestrian-oriented scale and urban density coupled with ecological, economical, and socially sustainable design. These new, sustainable developments can serve as models for the retrofitting of cities and suburbs now and in the future that can address the pragmatic and technical concerns of sustainable growth and economic viability while aspiring to the highest ideals of planning and design. Ecologist and biologists should be brought into the design process so planners and developers can better understand how urban design, infrastructure, and construction of the built environment can be compatible with the eco-system and complexity of urban life (Chambers [24]). Whereas this paper offers a conceptual framework for sustainable suburban living in the US in the $21^{\text {st }}$ Century, extensive data collection from growing suburbs can corroborate the points presented by the authors. This is left for future research.

\section{References}

[1] Howard, E., Tomorrow: A Peaceful Path to Real Reform, Routledge: London, 1998 (reissue).

[2] Barnett, J., The Elusive City: Five Centuries of Design, Ambition and Miscalculation, Harper \& Row: New York, 1986. 
[3] Waldheim, C., Landscape as urbanism, The Landscape Urbanism Reader, ed. C. Waldheim, Princeton Architectural Press: New York, pp. 35-54, 2006.

[4] Corner, J., Terra fluxus, The Landscape Urbanism Reader, ed. C. Waldheim, Princeton Architectural Press: New York, pp. 21-34, 2006.

[5] Urban Design Associates (UDA), The Urban Design Handbook: Techniques and Working Methods, W. W. Norton: New York, 2003.

[6] Congress for New Urbanism (CNU), Charter of the new urbanism, Chicago, IL. http://www.cnu.org/charter. Retrieved July 15, 2011.

[7] Gauzin-Muller, D., Sustainable Architecture and Urbanism: Concepts, Technologies, Examples, Birkhauser: Basel, Switzerland, 2002.

[8] Carter, A., Strategy and partnership in urban regeneration, Urban Regeneration: A Handbook, ed. P. Roberts \& H. Sykes, SAGE Publications: London, pp. 37-58, 2000.

[9] Hall, P., Regeneration policies for peripheral housing estates: Inward and outward-looking approaches, Urban Studies, Vol. 34, no. 5-6, pp. 873-890, 1997.

[10] Palen, J.J., The Suburbs, McGraw-Hill: New York, p. 42, 1995.

[11] Pisarski, A., Commuting in America: A National Report on Commuting and Trends, Eno Foundation for Transportation: Westport, Conn, 1987.

[12] Chow, R.Y., Suburban Space: The Fabric of Dwelling, University of California Press: Berkeley, 2002.

[13] Beedle, L.S., Ali, M.M., \& Armstrong, P.J., The Skyscraper and the City: Design, Technology, and Innovation, Edwin Mellen Press: Lewiston, NY, 2007.

[14] Langdon, P., A Better Place to Live: Reshaping the American Suburb, Harper Perennial: New York, 1994.

[15] Ebner, M.H., Suburbs and cities as dual metropolis: Evanston, IL, The Encyclopedia of Chicago, Chicago Historical Society: Chicago, 2005. http://www.enclopedia.chicagohistory.org/pages/438.html. Retrieved July 15, 2011.

[16] Makarewicz, C., Benedict, A., \& Marshall, C., The City of Evanston's transit oriented redevelopment, Communicating the Benefits of TOD: The City of Evanston's Transit-Oriented Redevelopment and the Hudson Bergen Light Rail Transit System, ed. Gorewitz, C. \& Ohland, G.

[17] Bordenaro, M., Architect as developer, Focus, December, American Institute of Architects: Chicago, 2005.

[18] Apartment Home Living, Luxury sophistication, 415 Apartments Printable Brochure-Evanston Apartments, p. 2, 2011. http://www.apartmenthome living.com/apartment-finder/415-Evanston-Il-60202-212223.pdf. Retrieved August 21, 2011.

[19] Macsai, J., Eye on Evanston: Another high-rise, Evanston Roundtable, March, 31, 2011. http://www.evanstonrondtable.com/main.asp?Section $\mathrm{ID}=20 \&$ SubSectionID=29\&ArticleID=3967. Retrieved August 21, 2011.

[20] Overholser, G., Sarasota Herald Tribune, October 13, 1999. 
[21] Olorunnipa, T., Coral Gables experiencing mini building boom, The Miami Herald, August, 14, 2011. http://www.miamiherald.com/2011/08/14 /2359434/coral-gables-experiencing-mini.html. Retrieved August 22, 2011.

[22] United Nations Department of Economic and Social Affairs (UNDESA), World Population to 2300, United Nations Publication: New York, 2004.

[23] CBS News, UN: World population increasingly urban, February 11, 2008. http//www.cbsnews.com/stories/2008/02/26/world/main3880698.shtml?sou rce-RSSattr=HOME_3880698. Retrieved August 22, 2011.

[24] Chambers, N.B., Urban Green: Architecture for the Future, Palgrave MacMillan: London, U.K., 2011. 